\title{
MATHEMATICAL MODEL FOR PREDICTING THE MAXIMUM WATER DEMAND OF CROPS
}

\author{
Bouzo, C. A. ${ }^{1} \&$ Norero SCH, A. L. ${ }^{2}$
}

\begin{abstract}
Diverse methods with different levels of complexity exist for the calculation of crop evapotranspiration. The understanding and quantification of evapotranspiration has advanced with the emergence of mathematical models to estimate the water demand of crops. The objective of this work is developing a mathematical model for the maximum water demand of crops, depending on phytometric and meteorological characteristics. The model is based on two main concepts: the maximum evapotranspiration and the energetic balance in the crops. The model was coded as macros of Visual Basic to be used in Microsoft ${ }^{\circledR}$ Excel. The model discriminates functional from structural variability of the micro-meteorology in the canopy. The model results for crops of cotton (Gossypium hirsutum L.), sunflower (Helianthus annuus L.), corn (Zea mays L.) and potato (Solanum tuberosum L.), showed a good agreement with data from the Penman-Monteith method.
\end{abstract}

Key words: Maximum evapotranspiration; Energetic balance; Radiation balance; Simulation.

\section{RESUMEN}

\section{Modelo matemático para predecir la demanda máxima de agua de los cultivos.}

En el cálculo de la evapotranspiración de los cultivos existen métodos con diferentes grados de complejidad. La aparición de modelos matemáticos para estimar la demanda de agua de los cultivos significó un avance en la comprensión y cuantificación de la evapotranspiración. El objetivo de este trabajo fue desarrollar un modelo matemático para estimar la demanda máxima de agua en cultivos agrícolas dadas algunas características fitométricas y meteorológicas. El modelo se desarrolló considerando dos conceptos principales: el de evapotranspiración máxima y balance energético de los cultivos. El mismo fue codificado con macros de Visual Basic para su uso con Microsoft ${ }^{\circledR}$ Excel. Finalmente, los resultados obtenidos permitieron discriminar en lo funcional y estructural la variabilidad de la micrometeorología en el dosel de varios cultivos. Se compararon

1.- Facultad de Ciencias Agrarias (UNL). Kreder 2805. (3080) Esperanza, provincia de Santa Fe. E-mail address: cbouzo@arnet.com.ar

2.- Facultad de Agronomía e Ingeniería Forestal, Pontificia Universidad Católica de Chile. Casilla 306. Santiago 22, Chile.

Manuscrito recibido el 12 de febrero de 2015 y aceptado para su publicación el 20 de mayo de 2015. 


\section{Bouzo et al.}

algunos resultados del modelo para cultivos de algodón (Gossypium hirsutum L.), girasol (Helianthus annuus L.), maíz (Zea mays L.) y papa (Solanum tuberosum L.) con datos provenientes del método de Penman-Monteith, habiéndose obtenidos aceptables aproximaciones.

Palabras clave: Evapotranspiración máxima; Balance energético; Balance de radiación; Simulación.

\section{INTRODUCTION}

The water demand in crops is directly related to the evapotranspiration (ET). Two separated processes contribute to ET: water is lost thorough the surface by evaporation and also by transpiration of the crop (Allen et al., 1998). Some of the variables to quantify this phenomenon are: (i) potential evapotranspiration (ETP), that is, the loss of water from a surface with vegetation with no hydric deficit (Lu et al., 2005); (ii) reference evapotranspiration (ETo), that is, evapotranspiration occurring in an extensive surface of 8 to $15 \mathrm{~cm}$ tall green grass, in active growth, and totally covering the soil (Doorenbos \& Kassam, 1980).

Methods to determine evapotranspiration are classified in direct, also called measurement methods, and indirect (Sánchez Martínez, 2001). Direct methods are numerous, among them, use of lysimeters, measurement of the xylem flow and hydrological balance (Jensen et al., 1990). Direct methods are more accurate, but due to difficulties in their application, indirect methods are more commonly used (Sánchez Martínez, 2001).

Several methods exist, with different complexity level, for the indirect determination of the evapotranspiration of crops (Doorenbos \& Pruit, 1976). The methods are based on: (i) air temperature and astronomic data (Thornthwaite, 1948; Blaney \& Criddle, 1950); (ii) temperature and relative humidity (Papadakis, 1965; Ivanov, 1954; Hargreaves, 1974); (iii) solar radiation (Turc, 1961; Jensen \& Haise, 1963); (iv) mass and energy balance (Penman, 1948; Penman-Monteith (Monteith, 1965); (v) relation between the tank evaporation and the evapotranspiration (Kashyap \& Panda, 2001). Other methods using acquisition and analysis of data from remote sensors have been developed to estimate the evapotranspiration of crops (Courault et al., 2005; Gordillo Salinas et al., 2014).

Even though all the mentioned methods are widely used, to understand the intervening factors and estimate the water demand of the crops, it is advisable to consider the continuous soil-plant-atmosphere. Any attempt to attribute the evapotranspiration process to only one factor can be useless or misleading (Sharma, 1985). In this sense the emergence of mathematical models to estimate the water demand means an advance in the understanding and quantification of the evapotranspiration in crops (Sellers et al., 1986; Norero, 1987; Flerchinger \& Pierson, 1991). In 1969, Norero proposed a new term: maximum evapotranspiration (ETmax) (Taylor \& Ashcroft, 1973), to account for the maximum demand of water of a crop without limitations of any kind and with full supply of soil water. For the calculation of ETmax the energy balance in the crop has to be considered, with main phytometrics variables of the crops. The calculation has an academic value since 